\title{
Isolation, Identification and Screening of the Yeast Flora from Indian Cashew Apple for Sugar and Ethanol Tolerance
}

\author{
Meghana V. Desai, Kavita V. Dubey, Babu V. Vakil and Vaijayanti V. Ranade*
}

\author{
Department of Microbiology, G.N. Khalsa College, Matunga, Mumbai-19, India
}

\begin{abstract}
Cashew apple juice is rich in fermentable sugars, minerals and vitamins, which makes it a suitable substrate for production of alcoholic beverages. In the present research work, indigenous flora of cashew apple (Indian variety) was studied. Seven morphologically different strains of Candida spp. were identified and checked for their sugar and ethanol tolerance. All seven isolates were able to tolerate sugar concentrations up to $25 \%$ but varied in their ethanol tolerance. Based on the above results it can be concluded that a high sugar and ethanol tolerant Candida spp. could be used as starter culture for commercial production of alcoholic beverages from cashew apple.
\end{abstract}

Keywords: Cashew apple juice, Alcoholic beverages, Candida spp., Sugar tolerance, Ethanol tolerance.

\section{INTRODUCTION}

Fermentations that involve production of ethanol are among the most ancient fermentation processes known. It is also said by some anthropologists that it was alcoholic fermentation and desire for alcohol that motivated humans to settle down and become agriculturists [1]. Yeasts play a key role in various fermentation processes e.g. alcoholic beverages like whisky, rum, beer and country liquors like feni as well as for the production of single cell proteins, fermented cheese and yoghurt [2].

Fruits are important substrates for fermented fruit beverages all over the world because they contain fermentable sugars. Virtually any fruit can be processed into an alcoholic beverage [3]. In India; many fermented alcoholic beverages are made from fruits like - apple, grapes, pineapple, cashew apple, jackfruit, banana etc. One of the common alcoholic beverages is feni. Feni is Indian hard liquor produced and consumed in Goa and made from alcoholic fermentation of cashew apple juice [4]. Cashew apple (Anacardium occidentale L.), belonging to family Anacardiaceae is one of the important nut crops of India. India is currently the second largest producer of cashew apple in the world after China [5]. This pseudo fruit has three to six fold more vitamin $C$ content than orange [6-9]. Based on external color of the fruit, cashew apple is classified into two varieties, red and yellow [7]. Cashew apple is a soft fibrous fruit that yields a highly nutritious juice called "niro" which is good for digestion and also can be utilized for the preparation of several value added products.

*Address corresponding to this author at the Department of Microbiology, G.N. Khalsa College, Matunga, Mumbai-19, India; Tel: 981993 5396; Fax: 24016815; E-mails: vaijayantiranade@gmail.com,v_ranade2004@yahoo.co.uk
Cashew apple possesses anti-tumor activity [8] and is also known to inhibit growth of gastritis causing bacteria such as Helicobacter pylori [9, 10]. Cashew nut possesses astringent qualities that are now used in topical creams for treatment of warts, moles and other unwanted skin growths [11].

Cashew is rich in fermentable sugars, minerals and vitamins [12]. It is also cheap, drought-resistant and easily available, hence a good raw material for alcoholic beverage production. Cashew contains approximately $30 \%$ fermentable sugars (fructose and glucose), which can be utilized for fermentation of ethanol [13]. Investigation of the alcoholic fermentation of cashew apple is not new but microbial aspects of feni fermentation have not received much attention as it has remained a household small scale unorganized business in the Coastal regions of east India such as Goa and Konkan.

Due to highly perishable nature of the fruit, they are very susceptible to injury and rapid microbial deterioration once harvested. These factors together with the difficulties in the collection and transport of ripe fruits have deterred the commercial utilization of cashew apple. Only a fraction is being utilized for feni preparation. Imagine the loss when for every ton of nut produced $\sim 5$ tons of cashew apples go waste [4].

Ethanol production by yeasts is considered as one of the oldest industrial processes. The most commonly used strain for industrial ethanol production is Saccharomyces cereviciae. In assessing any yeast strain for industrial use, specific physiological properties are required to be evaluated [14] some of the important properties for use in industrial ethanol production are sugar tolerance, ethanol tolerance and invertase activity [15].

() 2012 Lifescience Globa 


\section{MATERIALS AND METHODS}

\section{Isolation and Microscopic Examination of the Yeast Isolates from Cashew Apple}

Fresh cashew apple fruits were purchased from the local market. The cashew nut was removed, and the fruits (peduncle) were rinsed thoroughly several times in distilled water in a laminar air flow bench where asepsis was maintained. The fruits were then chopped into small pieces and subjected to fruit press for extraction. The extracted juice was serially diluted in saline and plated on Oxytetracycline Glucose Agar base medium used for selective isolation of yeasts [16]. (Composition: g/L: dextrose: 20; yeast extract: 5; agar: 12; $\mathrm{pH}: 7.0 \pm 0.2$ and oxytetracycline: $100 \mathrm{mg}$ ). Plates were incubated at $30^{\circ} \mathrm{C}$, for $48 \mathrm{hrs}$. Morphologically different colonies were selected and purified by subsequent streaking on Glucose Yeast Extract agar medium composed of $(\mathrm{g} / \mathrm{L})$ : dextrose, 5 ; yeast extract, 20; agar, 15; oxytetracycline: $100 \mu \mathrm{g} / \mathrm{ml} ; \mathrm{pH}: 7.0 \pm 0.2$. The isolates were Gram stained and examined on Biovis Image analyzer using $100 \mathrm{X}$ oil immersion lens.

The isolates obtained were identified using ID $32 \mathrm{C}$ a standardized system (BioMerieux, France), containing identification software for yeasts. Yeast suspensions of $24 \mathrm{~h}$ old culture whose turbidity was adjusted to 2 using ATB Densitometer McFarland was transferred into $2 \mathrm{ml}$ of $\mathrm{API}$ suspension medium \{Composition in $(\mathrm{g} / \mathrm{L})$ : $\left(\mathrm{NH}_{4}\right)_{2} \mathrm{SO}_{4}: 5 ; \mathrm{KH}_{2} \mathrm{PO}_{4}: 0.31$; $\mathrm{K}_{2} \mathrm{HPO}_{4}: 0.45 ; \mathrm{Na}_{2} \mathrm{PO}_{4}: 0.92 ; \mathrm{NaCl}: 0.1 ; \mathrm{CaCl}_{2}: 0.05$; $\mathrm{MgSO}_{4} .7 \mathrm{H}_{2} \mathrm{O}: 0.2$; L- histidine: 0.005 ; L-tryptophan: 0.02; L-methionine: 0.02; Agar:0.5; Vitamin solution: $1 \mathrm{ml}$;Trace elements: $10 \mathrm{ml}$;D/W: $989 \mathrm{ml}$; Final pH: $6.4 \pm$ 0.2 at $\left.25^{\circ} \mathrm{C}\right\}$. Of this medium $250 \mu$ l was transferred into $7 \mathrm{ml}$ of semi solid minimal medium composed of $(\mathrm{g} / \mathrm{L}):\left(\mathrm{NH}_{4}\right)_{2} \mathrm{SO}_{4}, 5 ; \mathrm{KH}_{2} \mathrm{PO}_{4}, 0.31 ; \mathrm{K}_{2} \mathrm{HPO}_{4}, 0.45 ;$ $\mathrm{Na}_{2} \mathrm{PO}_{4}, 0.92 ; \mathrm{NaCl}, 0.1 ; \mathrm{CaCl}_{2}, 0.05 ; \mathrm{MgSO}_{4} .7 \mathrm{H}_{2} \mathrm{O}$, 0.2; L-histidine, 0.005 ; L-tryptophan, 0.02 ; Lmethionine, 0.02 ; agar:0.5; vitamin solution: $1 \mathrm{ml}$; trace elements: $10 \mathrm{ml}$; deionized water, $989 \mathrm{ml}$; $\mathrm{pH}: 6.4 \pm 0.2$. As per the instructions of the manufacturer $135 \mu \mathrm{l}$ of this suspension was then transferred to each cupule of ID $32 \mathrm{C}$ strip. After incubation at $29^{\circ} \mathrm{C} \pm 2$ for $24-48 \mathrm{hrs}$, growth in each cupule was read using mini API instrument. Identification was done using database (V2) where the readings were interpreted by the identification software.

\section{Screening for Ethanol Tolerance}

Screening of the seven isolates (IS1 to IS7) for ethanol tolerance was carried out following the procedure by Ekunsanmi and Odunfa; 1990; Nowak et al. $1981[16,17]$.

To $50 \mathrm{ml}$ of autoclaved medium composed of $(\mathrm{g} / \mathrm{l})$ : $\mathrm{KH}_{2} \mathrm{PO}_{4}, 5 ;\left(\mathrm{NH}_{4}\right)_{2} \mathrm{SO}_{4}, 2 ; \mathrm{MgSO}_{4} .7 \mathrm{H}_{2} \mathrm{O}, 0.4$; yeast extract, 1 ; glucose, 20 ; pH: $3.7 \pm 0.2$ in $250 \mathrm{ml}$ sidearm flasks. Absolute ethanol was added constituting varying percentage of ethanol (6\%, $8 \%$ and $10 \%)$. A control flask was run parallel containing no ethanol. The flasks were inoculated with $100 \mu$ l of actively growing $(24 \mathrm{~h}$ \pm 2 ) cell suspension containing about $10^{6} \mathrm{cells} / \mathrm{ml}$ of respective cultures and incubated at $30^{\circ} \mathrm{C}$ for $72 \mathrm{hrs}$ in an orbital shaker cum incubator set at $150 \mathrm{rpm}[16,18]$. The optical density (OD) at $A_{615 n m}$ of each flask was measured colorimetrically using sterile MD5 medium as the blank.

Increase in the optical density with the increasing incubation time of the culture was considered as the evidence of growth. The concentration at which the growth of the yeast was just inhibited was considered as the highest concentration of ethanol that the strain could tolerate. Strains that showed growth in medium containing $8 \%$ ethanol $(\mathrm{v} / \mathrm{v})$ or more were selected for the further study (All the experiments were performed in triplicates).

\section{Sugar Tolerance of Ethanol Tolerant Yeasts}

The yeast isolates were screened for sugar tolerance in the Glucose yeast extract peptone medium composed of $(\mathrm{g} / \mathrm{L})$ : yeast extract, 10; peptone, 20 and glucose in varying concentrations of $150 \mathrm{~g}, 200 \mathrm{~g}$ and $250 \mathrm{~g}$.

To sterile medium, $100 \mu$ of actively growing (12 h old) bacterial cell suspension was added to each flask containing different sugar concentrations [16, 19]. The flasks were then incubated in orbital shaker cum incubator at $150 \mathrm{rpm}, 30^{\circ} \mathrm{C}$ for $60 \mathrm{hrs}$.

The turbidity was measured colorimetrically at $A_{540}$ $\mathrm{nm}$ every 12 hours up to 60 hours. The $\mathrm{pH}$ of samples was also measured at intervals of $12 \mathrm{hrs}$ to monitor the change in microbial growth during incubation.

\section{RESULTS AND DISCUSSIONS}

Numerous microbial species co-exist in nature and offer considerable difficulty in the isolation of one or few desired ones from the rest. In the present study cashew apple was examined for types of yeast flora and tested for ethanol and sugar tolerance. 


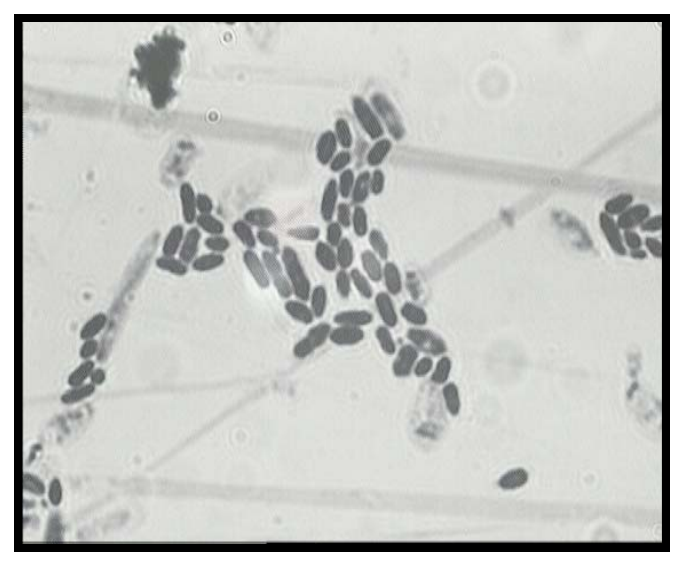

A) Candida krusei (IS1)

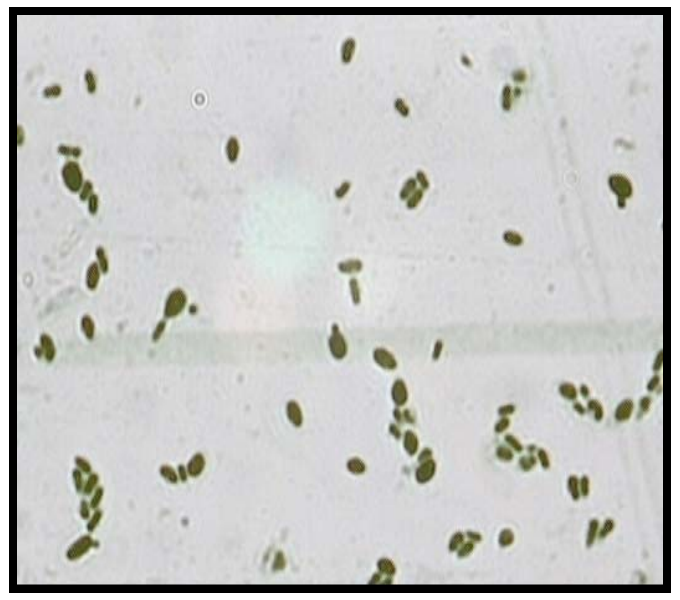

C) Candida norvegica (IS3 \& 6)

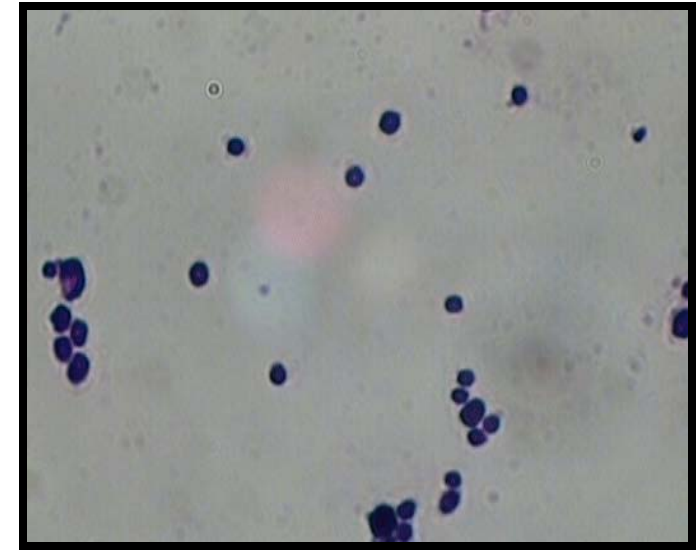

B) Candida parapsilosis (IS2 \& 5)

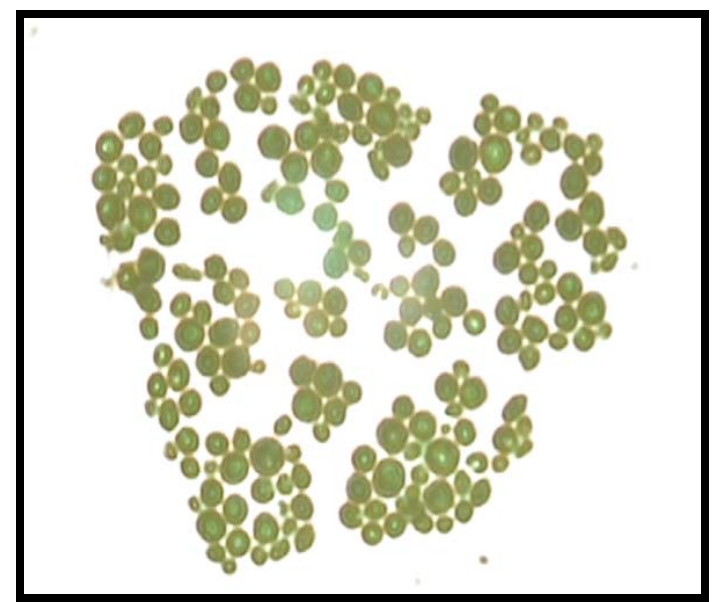

D) Candida colliculosa (IS4)

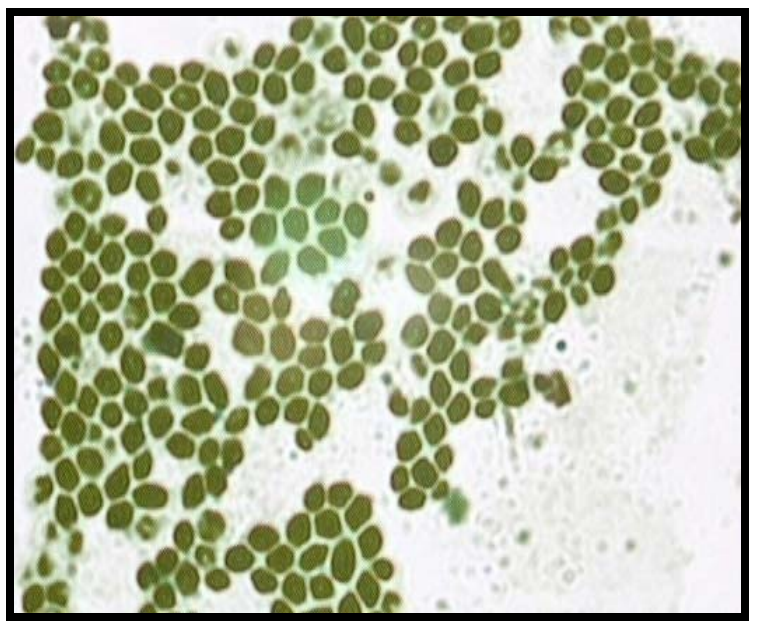

E) Candida magnolia (IS7)

Figure 1: (A-E) Monochrome stained yeast cells (isolated from Indian cashew apple) photographed under Biovis Image Analyzer.

The primary identification of the yeast isolates from cashew apple was done on the basis of morphological characteristics of colonies on selective medium (Oxytetracyclin agar). Monochrome staining was carried out to study the morphology of yeast isolates under Biovis Image analyzer with total magnification of
1000X. Seven isolates were then purified by transferring on Glucose Yeast Extract Agar slants. The isolates were identified at species level by using mini API (BioMerieux, France), a specific computer program developed for ID 32C strips (BioMerieux, France). This kit uses 30 miniaturized carbon assimilation 
Table 1: Morphological Colony Characteristics of the Cultures Isolated from Indian Cashew Apple

\begin{tabular}{|c|c|c|}
\hline Name of the Isolate & Colony morphology & Name of the identified isolate \\
\hline \hline IS1 & Cream color, flat, mucoidal, large scalloped colony & Candida krusei $^{\text {Candida parapsilosis }^{*}}$ \\
\hline IS2 & Cream color, umbonate colony & Candida norvegica\# $^{\text {Candida colliculosa }}$ \\
\hline IS3 & Cream color, mucoidal, circular colony & Candida parapsilosis $^{*}$ \\
\hline IS4 & Cream color, circular, umbonate colony & Candida norvegica\# $^{\text {Candida magnolia }}$ \\
\hline IS5 & Cream color, mucoid, ovoid colony & Cream color, concentric colony \\
\hline
\end{tabular}

carbohydrate substrates. On the basis of these tests the organisms were identified by comparing with the database.

All the seven isolates identified belonged to Candida species (Table 1). Survey of literature shows that Saccharomyces species are predominant members of the community [20], we report here the presence of Candida species to be predominant in case of Indian cashew apple.

\section{Screening for Ethanol Tolerance}

Medium MD5 was used for assessing the yeasts isolated from cashew apple for their ethanol tolerance. Table 2 shows the identities of the isolates and the minimum percentage of ethanol $(\mathrm{v} / \mathrm{v})$ which inhibited their growth.

Table 2: Ethanol Tolerance Levels of the Identified Yeast Strains

\begin{tabular}{|c|c|}
\hline Identified Isolate & Ethanol Tolerance $(\% \mathbf{v} / \mathbf{v})$ \\
\hline \hline Candida krusei (IS1) & 10 \\
\hline Candida norvegica (IS3) & 10 \\
\hline Candida magnoliae (IS7) & 10 \\
\hline Candida parapsilosis (IS2) & 08 \\
\hline Candida colliculosa (IS4) & 06 \\
\hline Candida norvegica (IS6) & 06 \\
\hline Candida parapsilosis (IS5) & 06 \\
\hline
\end{tabular}

The property of ethanol tolerance is important from commercial point of view, because of the fact that production of higher levels of ethanol requires the strain to be tolerant to higher concentrations of ethanol in the medium. Because plasma membrane of unicellular organisms is in direct contact with surrounding medium, it is likely that its characteristics will influence tolerance of cells to all kinds of changes occurring during fermentation [20]. However the physiological basis for ethanol tolerance in yeasts remains obscure [21].

IS1, IS3 and IS7 were ethanol tolerant yeast strains. This data also states that although ethanol production is traditionally associated with yeasts, not all yeasts are able to tolerate higher percentage of ethanol.

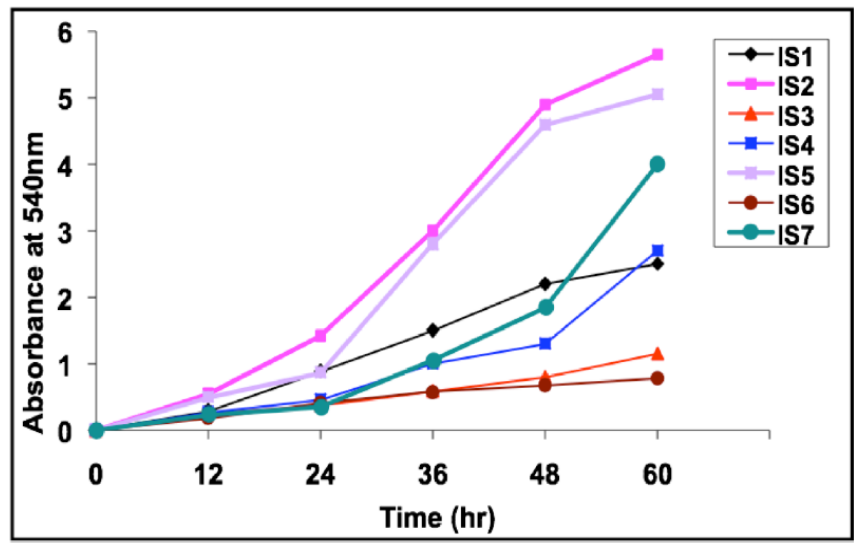

Figure 2: Growth (as absorbance at 540nm) of isolates in $15 \%$ glucose concentration.

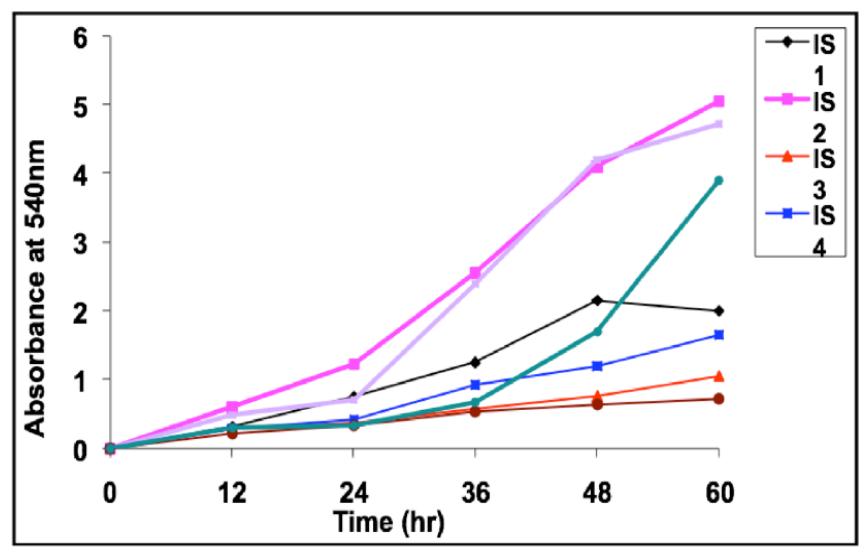

Figure 3: Growth (as absorbance at $540 \mathrm{~nm}$ ) of isolates in $20 \%$ glucose concentration. 


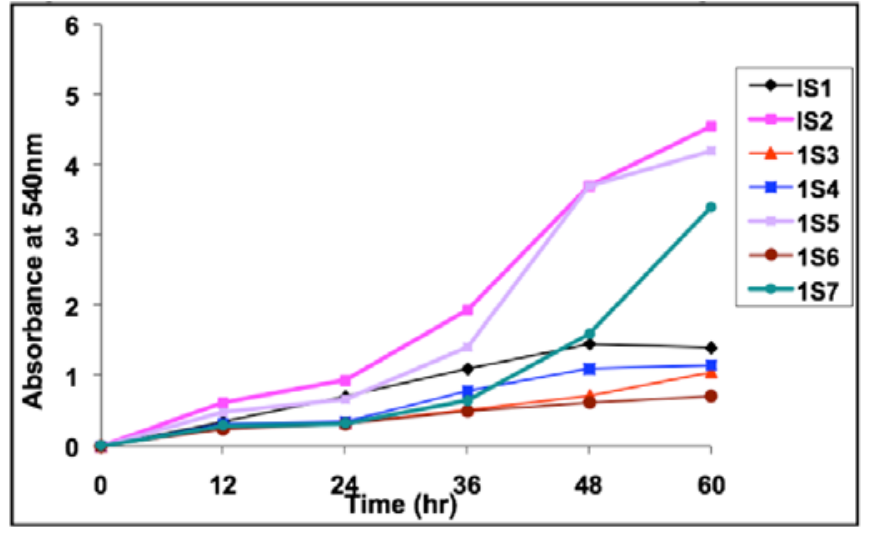

Figure 4: Growth (as absorbance at $540 \mathrm{~nm}$ ) of isolates in $25 \%$ glucose concentration.

\section{Sugar Tolerance of Ethanol Tolerant Yeasts}

Sugar utilization during fermentation is one of the important physiological features of yeast strains used for industrial ethanol production [16, 20, 22]. The present study was carried out to check for the sugar tolerance of the yeasts isolated from cashew apple juices, because tolerance of yeast strains to higher sugar concentration is necessary for optimum ethanol production. The work done clearly indicates that the tolerance of the cells decreased with increase in sugar (glucose) concentrations (Figures 1, 2 and 3). Though all the isolates were able to withstand the highest sugar concentration (25\%) the growth observed in $25 \%$ sugar containing medium was much less than that containing $15 \%$ sugar concentrations. At high sugar concentration osmotic pressure increases in the fermenting medium, and this is inhibitory to many yeasts. High osmotic pressure is associated with increased stress on the organisms that grow in the medium. This rapid change in the physiological condition during fermentation imposes water and ethanol stress on yeast cells [2224].

All the seven strains of Candida (IS1 to IS7) were able to grow in all sugar concentrations from 15\%-25\% in the medium (Figures 2-7). The isolates IS1, IS3 and IS7 were able to withstand the osmotic stress as they could grow in medium containing higher percentage of sugar $(25 \%)$.

Highest growth was observed at $25 \%$ sugar concentration within first $12 \mathrm{~h}$ of incubation for almost all the isolates. Tolerance of isolates reduced with the increasing concentration of sugar. Yeasts utilize sugars as the principal source of carbohydrates to produce alcohol and acid and so increased growth resulted in sudden drop in $\mathrm{pH}$ after $24 \mathrm{~h}$ and towards the end of incubation period. In this study, inhibitory effect of sugar was observed on all the isolates irrespective of the fact that sugar is the chief carbon source required for yeast growth. As a result of this, increase in sugar concentration showed a reduction in the optical density.

One important reason for screening of the yeasts for ethanol and sugar tolerance is that, not all the yeasts that tolerate higher levels of ethanol are able to produce ethanol at desired concentrations. IS1, IS3 and IS7 were ethanol tolerant and also grew in medium with higher percentage of sugar. (IS1) Candida krusei, (IS3) Candida norvegica and (IS7) Candida magnoliae showed tolerance to higher concentration of sugar and ethanol and hence can be considered suitable candidates for further evaluation for the suitability for production of wines with higher alcohol content.

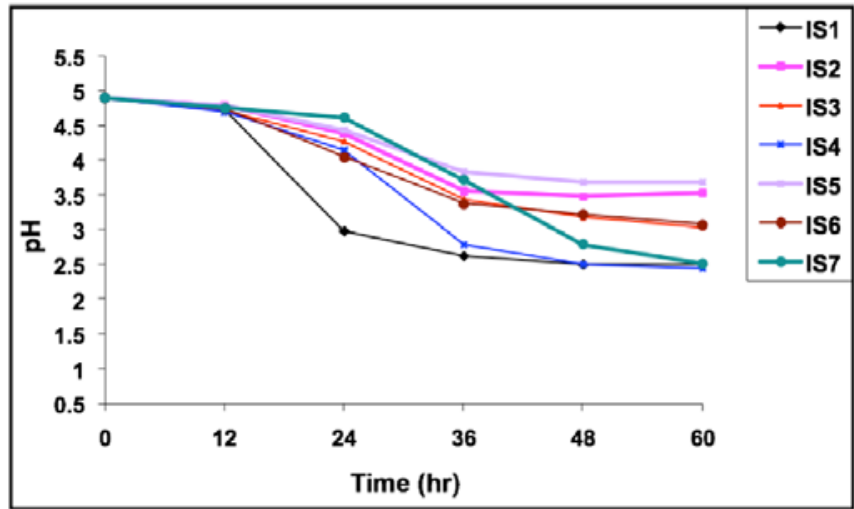

Figure 5: Growth (as change in $\mathrm{pH}$ ) of isolates in $15 \%$ glucose concentration.

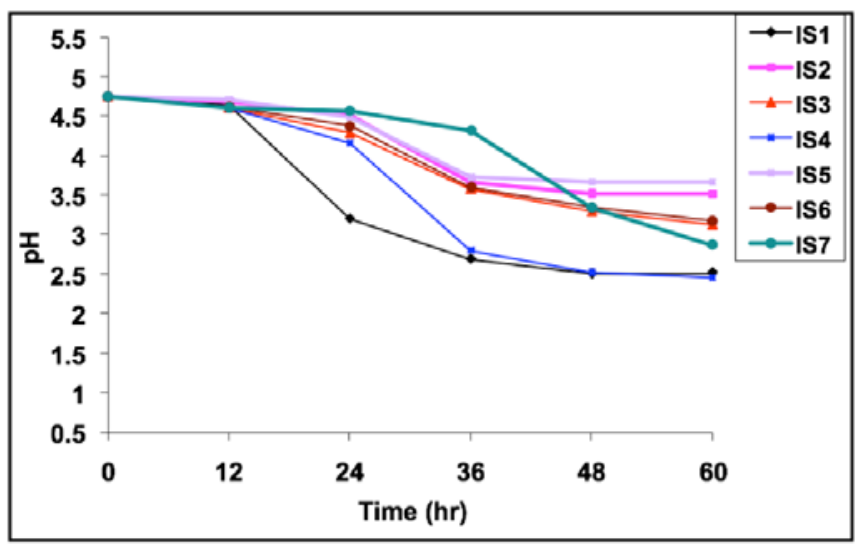

Figure 6: Growth (as change in $\mathrm{pH}$ ) of isolates in $20 \%$ glucose concentration.

\section{CONCLUSIONS}

Isolation of high ethanol and sugar tolerant yeast (predominantly Candida sp.) from cashew apple juice is an attractive alternative other than the traditional 


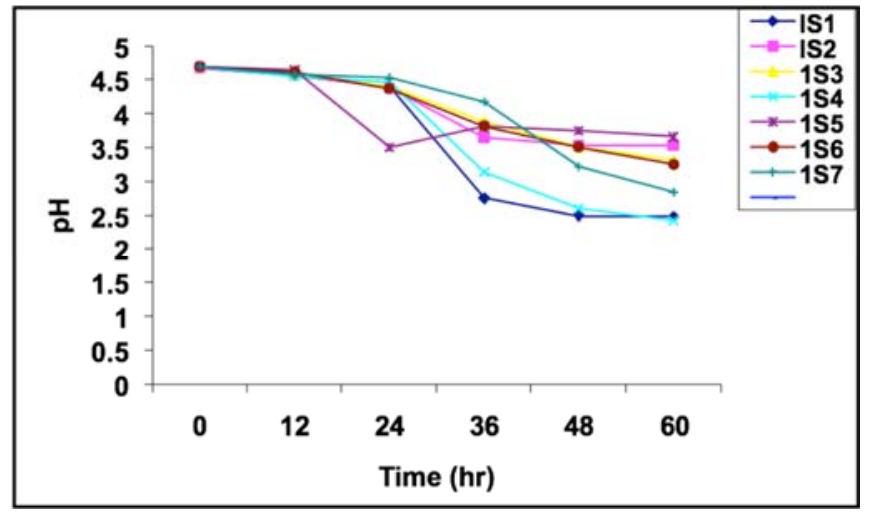

Figure 7: Growth (as change in $\mathrm{pH}$ ) of isolates in $25 \%$ glucose concentration.

culture Saccharomyces species. This study also reveals the need to look for such fruits which go waste most of the times. This study might also help in yielding new strains of yeasts and their potential use as starter cultures for alcohol production.

\section{ACKNOWLEDGEMENT}

We thank Institute of Chemical Technology (ICT); Matunga, Mumbai 400 019, India for offering Biovis Image analyzer for the microscopic examination of the isolates, and Metropolis; Andheri, Mumbai 400 058, India for their help in carrying out culture identification of the isolates using ID32 C API system.

\section{REFERENCES}

[1] Steinkraus K. Origin and history of food fermentation: Handbook of food and beverage fermentation technology, Marcel, Dekker, Inc. New York. Basel 2004; p. 3.

[2] Steinkraus K. Handbook of indigenous fermented foods, New York, Marcel Dekker. Inc., 1983; p. 305.

[3] Prescott and Dunn. Industrial Microbiology (4 ${ }^{\text {th }}$ ed.); Chapman and Hall Publication, London 1981.

[4] Battcock M, Azam S. Fermented fruits and vegetables: A global perspective. Food and agriculture organization United Nations (FAO), FAO agricultural services bulletin-134, Daya Publishing House, Delhi 2001; p. 29. http://www.fao.org/docrep/x0560e/x0560e00.html

[5] Salunkhe K, Kadam S. Cashew- Handbook of fruit science and technology: Production, composition, storage and processing. Marcel Dekker, Inc New York /Basel/ Hong Kong 1995; pp. 509-521.

[6] Costa J, Felipe F, Hernandez G, Brasil M. Production and characterization of the cashew apple (Anacardium occidentale L.) and guava (Psidium guajava I.) fruit powders. J Food Proces Preser 2009; 33: 299-12. http://dx.doi.org/10.1111/j.1745-4549.2008.00342.x

[7] Price L, Holanda L, Moura F, Maia A, Martins B. Cien. Agron 1975; 5: 61-5.

[8] Moura H. Qualidade de pedúnculos de clones de cajueiro anãoprecoce (Anacardium occidentale L. var. nanum) irrigados. Master'sThesis, Universidade Federal do Ceará, Fortaleza, Brazil 1998.
[9] Franco M, Janzantti S. Aroma of minor tropical fruits. Flavour Fragr J 2005; 20: 358-71. http://dx.doi.org/10.1002/ffj.1515

[10] Soares F, Pereira T, Marques M, Monteiro R. Volatile and non-volatile chemical composition of the white guava fruit (Psidium guajava L.) at different stages of maturity. Food Chem 2007; 100: 15-21. http://dx.doi.org/10.1016/j.foodchem.2005.07.061

[11] Figueiredo R, Lajolo F, Alves E, Cunha F. Physical-chemical changes in the early dwarf cashew pseudo fruits during development and maturation. Food Chem 2002; 77: 343-7. http://dx.doi.org/10.1016/S0308-8146(01)00358-2

[12] Kubo I, Ochi M, Vieria P, Komatsu S. Antitumor agents from the cashew (Anacardium occidentale) apple juice. J Agri Food Chem 1993; 41: 1012-5. http://dx.doi.org/10.1021/jf00030a035

[13] Kubo J, Lee J, Kubo I. Anti-Helicobacter pylori agents from the cashew apple. J Agric Food Chem 1999; 47: 533-37. http://dx.doi.org/10.1021/jf9808980

[14] Carvalho R. O setor sucroalcooleiro em perspectiva, Conjuntura agropecuária: Sucroalcooleiro, EMBRAPA 2006.

[15] Cashew oil: Culinary and cosmetic usage; http://www.africajou.com.

[16] Anita S, Punita S, Saran K, Namita S, Bishnoi N. Comparative study on ethanol production from pretreated sugarcane bagasse using immobilized Saccharomyces cerevisiae on various matrices. Renewable Energy 2013; 50: 488.

http://dx.doi.org/10.1016/j.renene.2012.07.003

[17] Garruti S, Franco M, Silva P, Janzantti S, Alves L. Assessment of aroma impact compounds in a cashew apple based alcoholic beverage by GC-MS and GC-olfactometry. Lebensmitte-Wissenschaft Technol 2006; 37: 373-8. http://dx.doi.org/10.1016/j.Iwt.2005.02.006

[18] Ekunsanmi J, Odunfa S. Ethanol tolerance, sugar tolerance and invertase activities of some yeast strains isolated from the steep water of fermenting cassava tubers. J Appl Bacteriol 1990; 69: 672-5. http://dx.doi.org/10.1111/j.1365-2672.1990.tb01561.x

[19] Jimenez J, Benitez T. Characterization of wine yeasts for ethanol production. Appl Microbiol Biotechnol 1986; 25: 1504. http://dx.doi.org/10.1007/BF00938939

[20] Herrera G. Yeasts and molds-Methods in biotechnology: Food microbiology protocols by Spencer T. and Ragout S. Humana Press Totowa, New Jersey 2001; 14: 27-28.

[21] Nowak M, Strehaiano P, Moreno M, Goma G. Alcoholic fermentation: On the inhibitory effect of ethanol. Biotechnol Bioeng 1981; 23: 201-11.

http://dx.doi.org/10.1002/bit.260230113

[22] Wharta A, Moreira B, Mancini J. Identificacaoe atividade antioxidante dos principais compostos fenolicos presents no sucoe na castanha do caju. In: Anais do XIX Congresso Brasileiro de Cienncia e Tecnologia de Alimentos Estrate'gia para o Desenvolvimento. Recife, PE: SBCTA (CDROM) 2004.

[23] Osho A. Ethanol and sugar tolerance of wine yeasts isolated from fermenting cashew apple juice. Afr J Biotechnol 2005 4: 660-2. http://www.academicjournals.org/AJB

[24] Tanghe A, Prior B, Thevelein J. Yeast responses to stressesYeast handbook: Biodiversity and eco-physiology of yeasts. Springer, Berlin Heidelberg, New York 2006.

[25] Rose AH, Harrison JS. The Yeasts: Yeast and the environment. Academic Press Inc. (London) Ltd. 1987; 1: 623.

[26] Panesar S, Marwaha S, Kennedy F. Comparison of ethanol and temperature tolerance of Zymomonas mobilis strain in glucose and molasses medium. Indian J Biotechnol 2007; 6 : 
74-7. http://nopr.niscair.res.in/bitstream/123456789/3017/1/ IJBT 6(1) 74-77

[27] Gump B, Zoecklein B, Fugelsang K. Prediction of prefermentation nutritional status of grape juice. The formol method: in Methods in Biotechnology: Food Microbiology

Protocols by Spencer J. and Ragout S. Humana Press Totowa, New Jersey 2001; 14: 288-89.

Received on 23-10-2012

Accepted on 12-12-2012

Published on 31-12-2012

DOI: http://dx.doi.org/10.6000/1927-3037.2012.01.04.6

(C) 2012 Desai et al.; Licensee Lifescience Global.

This is an open access article licensed under the terms of the Creative Commons Attribution Non-Commercial License (http://creativecommons.org/licenses/by-nc/3.0/) which permits unrestricted, non-commercial use, distribution and reproduction in any medium, provided the work is properly cited. 